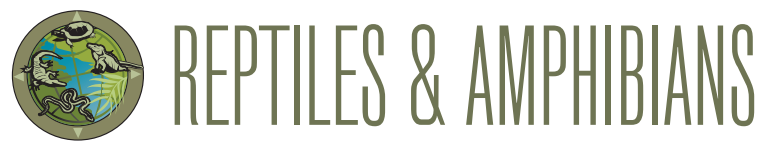

\title{
Predation on Rainbow Ameivas, Holcosus undulatus (sensu lato), and a Second Record of Predation on $H$. amphigrammus (Smith and Laufe 1945) by a Terciopelo (Bothrops asper) in Veracruz, Mexico
}

Rene Avalos Vela, Jorge Luis Castillo Juárez, and Ángel Iván Contreras Calvario

Universidad Veracruzana, Facultad de Ciencias Biológicas y Agropecuarias, Camino Viejo Peñuela-Amatlán de los Reyes. S/n. 94945. Municipio, Amatlán de los Reyes, Veracruz, México (renevela@live.com.mx)

Tn a major re-evaluation of the Holcosus undulatus complex (generally known as Rainbow Ameivas), Meza-Lázaro and Nieto-Montes de Oca (2015) elevated a number of taxa, including $H$. amphigrammus, to species. Holcosus undulatus (sensu lato) is a terrestrial teiid of medium size (SVL to 111 $\mathrm{mm}$; Ramírez-Bautista 1997) that is active by day and seeks shelter in leaf litter and burrows at night (Smith and Taylor 1966; Macip-Ríos et al. 2013; Ramírez-Bautista et al. 2014). In Mexico, lizards in this complex range along the Pacific ver- sant from Nayarit to Chiapas and on the Atlantic side from Tamaulipas south through the Yucatan Peninsula to Costa Rica at elevations of $0-800$ m asl (Ramírez-Bautista et al. 2014; CONABIO 2019).

Little is known about predators of Rainbow Ameivas, although most are thought to be snakes (Table 1). PerézHigareda et al. (2007) reported the predation of $H$. undulatus $(=H$. amphigrammus $)$ in the Tuxtlas region of Veracruz by the Salmon-bellied Racer (Mastigodryas melanolomus), the

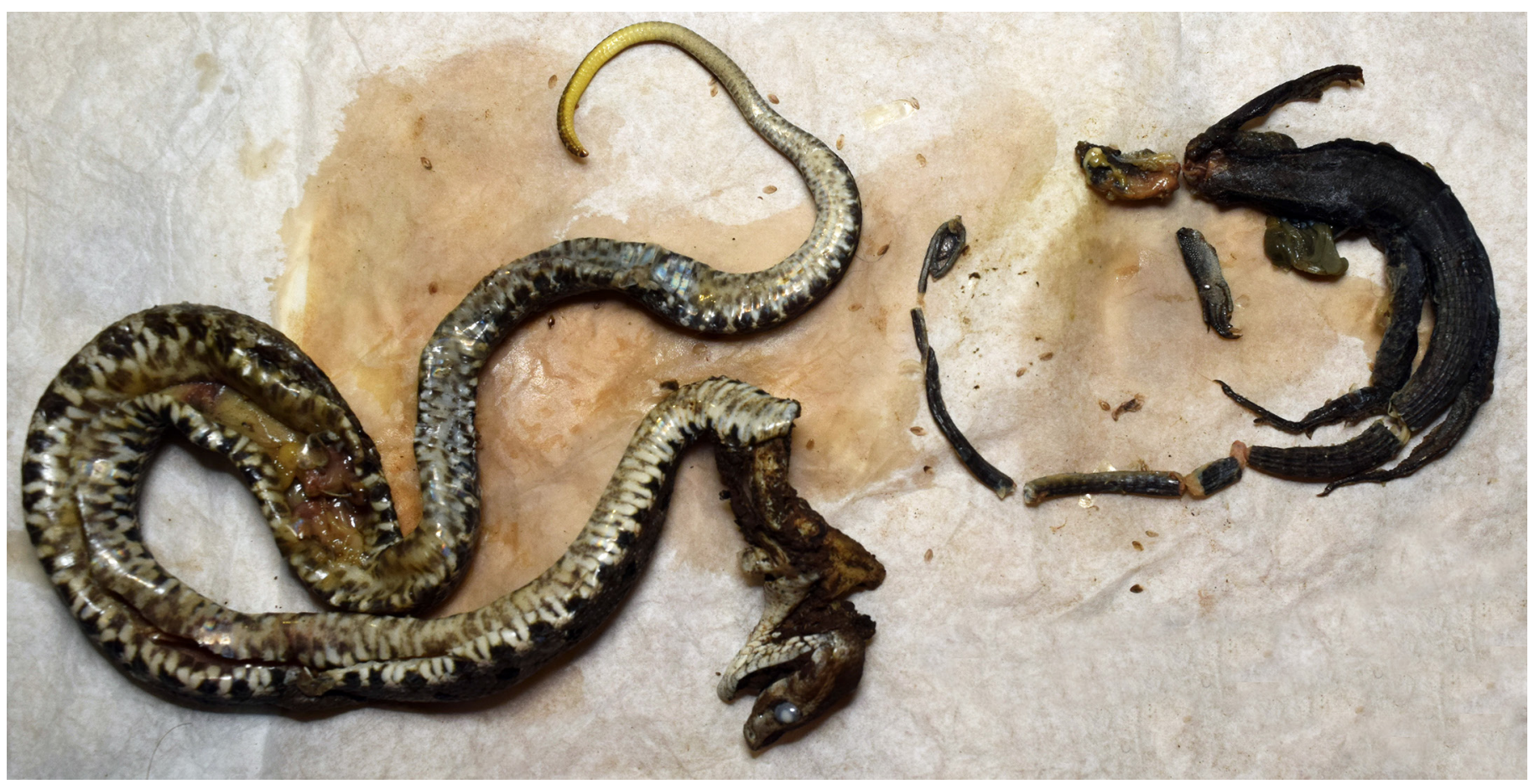

Fig. 1. A Terciopelo (Bothrops asper) (ITSZ-R-S-200) found dead in Cuichapa, Veracruz, México, with a prey item identified as a Rainbow Ameiva (Holcosus amphigrammus) (ITSZ-R-L-300). Photograph by Rene Avalos Vela. 
Table 1. Documented predators of Rainbow Ameivas, Holcosus undulatus (sensu lato), in Mexico and Central America. Names of prey species reflect current taxonomy (Meza-Lázaro and Nieto-Montes de Oca 2015; Mesoamerican Herpetology 2020; Uetz et al. 2020). Except for prey identified as Holcosus gaigeae or $H$. hartwegi, which were identified as such in the references listed, all other sources had identified lizards as either Ameiva undulata or Holcosus undulatus. For those records marked with an asterisk $\left(^{*}\right)$, we were unable to determine the current taxonomic status of the species because multiple taxa previously assigned to $A$. undulata $(=H$. undulatus) occur in the areas covered by those accounts.
Predator
Prey
Locality
Reference

\section{REPTILIA}

\section{Squamata: Dipsadidae}

Mexican Snake Eater

Clelia scytalina

H. amphigrammus Veracruz, México

Pérez-Higareda et al. (2007)

Common Road Guarder

Conophis lineatus

H. gaigeae

Yucatán, México

Gómez de Regil and Escalante-Pasos (2017)

Striped Road Guarder

Conophis vittatus

H. sinister

Jalisco, México

Madrid and Cifuentes (2012)

\section{Squamata: Colubridae}

Black-tailed Cribo

Drymarchon corais

A. undulata*

-

Campbell (1999)

Guatemalan Milksnake

Lampropeltis abnorma

H. gaigeae Yucatán, México

Carbajal-Márquez et al. (2019)

Atlantic Central American Milksnake

Lampropeltis polyzona

H. amphigrammus Veracruz, México Pérez-Higareda et al. (2007)

Salmon-bellied Racer

Mastigodryas melanolomus

H. amphigrammus Veracruz, México

Pérez-Higareda et al. (2007)

Neotropical Whipsnake

Masticophis mentovarius

A. undulata*

$-$

Campbell (1999)

Squamata: Elapidae

Variable Coralsnake

Micrurus diastema

Squamata: Viperidae

Cantil

Agkistrodon bilineatus

Eyelash Viper

Bothriechis schlegelii

H. gaigeae

Yucatán, México

Greene (1973)

Terciopelo

Bothrops asper
Hog-nosed Pitviper
Porthidium nasutum

H. parvus

Guanacaste, Costa Rica Savage (2002)

H. parvus

Guanacaste, Costa Rica Morgan and Barrio-Amorós (2015)

Porthidium nasutum

H. amphigrammus

Veracruz, México

Buttenhof and Vogt (1997)

H. amphigrammus

Veracruz, México

This paper

\section{Squamata: Xenosauridae}

Knob-scaled Lizard

Xenosaurus grandis

H. hartwegi

Chiapas, México

Paredes-Montesinos et al. (2015)

Xenosaurus grandis

H. amphigrammus

Veracruz, México

Ballinger et al. (1995)

\section{AMPHIBIA}

\section{Gymnophiona: Dermophiidae}

Mexican Caecilian

Dermophis mexicanus

A. undulata*

Chiapas, México

Moll and Smith (1967) 

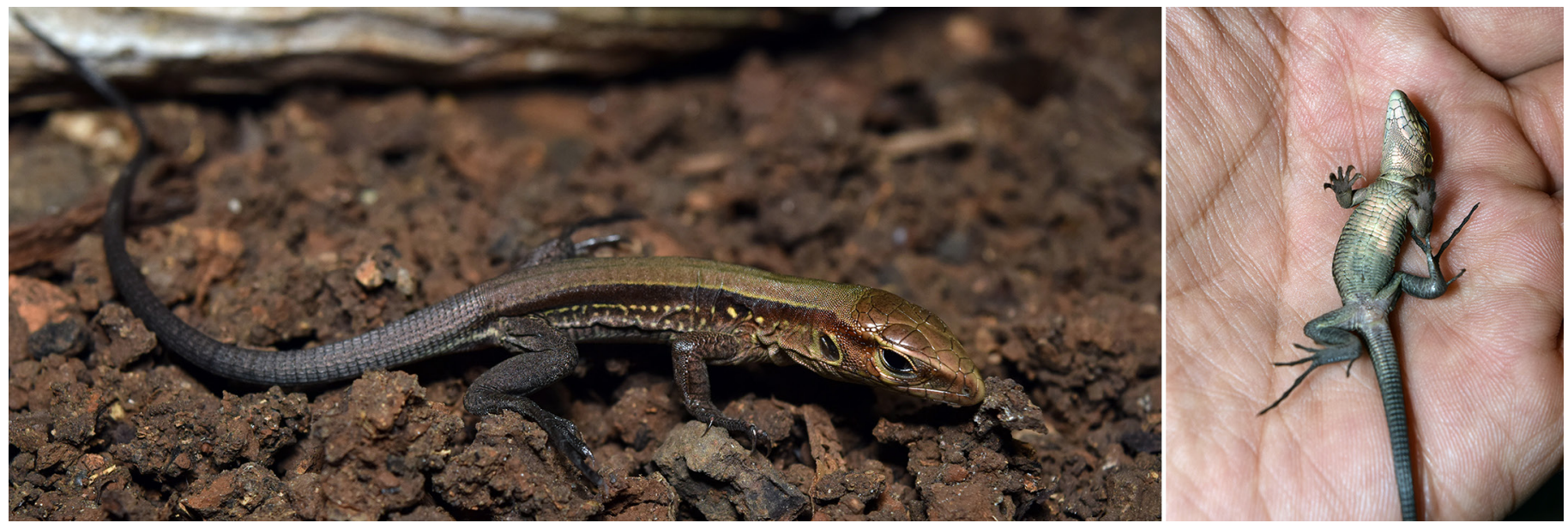

Fig. 2. A juvenile Rainbow Ameiva (Holcosus amphigrammus) encountered at night in Cuichapa, Veracruz, México. Photographs by Rene Avalos Vela.

Atlantic Central American Milksnake (Lampropeltis polizona), and the Mexican Snake Eater (Clelia scytalyna), although for the latter two species they listed only the genus Holcosus; we infer that this was $H$. undulatus ( $=H$. amphigrammus) given that it is the only species of the genus that occurs in the region (Smith and Laufe 1945). Campbell (1999) included H. undulatus (sensu lato) in the diet of the Common Road Guarder (Conophis lineatus), but Gómez de Regil and Escalante-Pasos (2017) documented this species preying on $H$. gaigeae. Ballinger et al. (1995) tentatively reported Ameiva or Aspidocelis ingested by Xenosaurus grandis, but we have never observed any species of Aspidocelis in Cuautlapan nor were any reported by Cerón de la Luz et al. (2016).

At about noon on 27 December 2019, we observed a dead juvenile Terciopelo (Bothrops asper) (Instituto Tecnológico Superior de Zongolica, ITSZ-R-S-200) on the side of a trail in the Municipality of Cuichapa, Veracruz, Mexico $\left(18^{\circ} 46^{\prime} 27.4{ }^{\prime \prime} \mathrm{N}, 96^{\circ} 51^{\prime} 02.6^{\prime \prime} \mathrm{W}\right)$. A recent injury behind the head indicated that it had been killed by humans. When we examined the specimen at a later date, we noticed a bulge in its gut, which we dissected to reveal a juvenile Holcosus amphigrammus (ITSZ-R-L-300) (Fig. 1).

Buttenhoff and Vogt (1997) described a juvenile Terciopelo from Montepio, Veracruz, that contained an Ameiva undulata $(=H$. amphigrammus) in its stomach, and the authors hypothesized that the snake had ambushed its prey due to the implausibility of predation by chase given the speed of the lizard. Furthermore, because B. asper is active mainly at night (Wasko and Sasa 2009) and Rainbow Ameivas are diurnal, we believe that the juvenile viperid encountered the lizard while foraging at night. This assumption was reinforced by a nighttime encounter with a juvenile H. amphigrammus in nearby Cuichapa (Fig. 2) that was under a $\log$ and did not try to escape when exposed. Additionally, the predation event described above almost certainly occurred during the previous night given the modest state of digestion of the prey.
This is the first account of predation by a Terciopelo on a Rainbow Ameiva in this mountainous region of Veracruz and only the second ever, 23 years after the first report by Buttenhoff and Vogt (1997) in the Tuxtlas region. These are the only instances of predation by $B$. asper on $H$. amphigrammus, although Sasa et al. (2009) listed H. festivus in the diet of this viperid in Costa Rica.

\section{Acknowledgements}

We thank Guillermina Vela for providing us with material to preserve and store the specimen during our fieldwork, Erasmo Cázares Hernández for cataloging the specimens in the Instituto Tecnológico Superior de Zongolica collection, and Brett Butler for reviewing the language of this manuscript.

\section{Literature Cited}

Ballinger, R.E., J. Lemos-Espinal, S. Sanoja-Sarabia, and N.R. Coady. 1995. Ecological observations of the lizard, Xenosaurus grandis in Cuautlapan, Veracruz, México. Biotropica 27: 128-132.

Buttenhoff, P.A. and R.C. Vogt. 1997. Historia natural de especies (Bothrops asper), pp. 478-480. In: E. González-Soriano, R. Dirzo, and R.C. Vogt (eds.), Historia Natural de Los Tuxtlas. Universidad Nacional Autónoma de México, D.F., México.

Campbell, J.A. 1999. Amphibians and Reptiles of Northern Guatemala, the Yucatán, and Belize. Animal Natural History Series, Volume 4. University of Oklahoma Press, Norman, Oklahoma, USA.

Carbajal-Márquez, R.A., C.M. García-Balderas, T. Ramírez-Valverde, J.R. CedeñoVázquez, and N.G. Blanco-Campos. 2019. New prey items in the diet of snakes from the Yucatán Peninsula, México. Cuadernos de Herpetología 33: 71-74.

Cerón de la Luz, N.M., J.A. Lemos-Espinal, and G.R. Smith. 2016. A diversity and conservation inventory of the herpetofauna of the Cuautlapan Valley, Veracruz, México. Zootaxa 4205: 127-142.

CONABIO (Comisión Nacional para el Conocimiento y Uso de la Biodiversidad). 2019. Lagartija arcoiris. Holcosus undulatus. EncicloVida. <http://enciclovida. $\mathrm{mx} / / 26869 /$ especies $>$.

Gómez-de Regil, G.M. and J.A. Escalante-Pasos. 2017. Conophis lineatus (Duméril, Bibron and Duméril 1854). Diet. Mesoamerican Herpetology 4: 180-181.

Greene, H.W. 1973. The Food Habits and Feeding Behavior of New World Coral Snakes. Unpubl. M.S. Thesis, University of Texas at Arlington, Arlington, Texas, USA.

Macip-Ríos, R., S. López-Alcaide, and A. Muñoz-Alonso. 2013. Abundancia, uso de hábitat, microhábitat y hora de actividad de Ameiva undulata (Squamata: Teidae) en un paisaje fragmentado del Soconusco chiapaneco. Revista 
Mexicana de Biodiversidad 84: 622-629.

Madrid, C. and P. Cifuentes. 2012. Diet and mortality of the snake Conophis vittatus in western Mexico. Boletín de la Asociación Herpetológica Española 23(2): 32-35.

Mesoamerican Herpetology. 2020. Herpetofaunal List for Mesoamerica. <http:// mesoamericanherpetology.com/taxonomic-list.html>.

Meza-Lázaro, R.N. and A. Nieto-Montes de Oca. 2015. Long forsaken species diversity in the Middle American lizard Holcosus undulatus (Teiidae). Zoological Journal of the Linnean Society 175: 189-210. DOI: 10.1111/ zoj. 12264 .

Moll, E.O. and H.M. Smith. 1967. Lizards in the diet of an American caecilian. Chicago Academy of Sciences, Natural History Miscellanea 187: 1-2.

Morgan, R. and C. Barrio-Amorós. 2015. Bothriechis schlegelii. Diet. Mesoamerican Herpetology 2: 345-347.

Paredes-Montesinos, R., E. García-Padilla, and V. Mata-Silva. 2015. Porthidium nasutum. Diet. Mesoamerican Herpetology 2: 350-351.

Pérez-Higareda, G., M.A. López-Luna, and H.M. Smith. 2007. Serpientes de la Región de Los Tuxtlas, Veracruz, México: Guía de Identificación Ilustrada. Universidad Nacional Autónoma de México, México D.F., México.

Ramírez-Bautista, A. 1977. Algunos Anfibios y Reptiles de la Región de Los Tuxtlas, Veracruz. Unpubl.Tesis de Licenciatura, Universidad Veracruzana, Xalapa, Veracruz, México.
Ramírez-Bautista, A., U. Hernández-Salinas, R. Cruz-Elizalde, C. Berroizabal-Islas, D. Lara-Tufiño, I. Goyenecgea-Mayer, and J.M. Castillo-Cerón. 2014. Los Anfibios y Reptiles de Hidalgo, México: Diversidad, Biogeografia y Conservación. Sociedad Herpetológica Mexicana, A.C. México D.F., México.

Sasa, M., D.K. Wasko, and W.W. Lamar. 2009. Natural history of the terciopelo Bothrops asper (Serpentes: Viperidae) in Costa Rica. Toxicon 54: 904-922.

Savage, J.M. 2002. The Amphibians and Reptiles of Costa Rica: A Herpetofauna between Two Continents, between Two Seas. The University of Chicago Press, Chicago, Illinois, USA.

Smith, H.M. and L.E. Laufe. 1945. Mexican amphibians and reptiles in the Texas Cooperative Wildlife Collections. Transactions of the Kansas Academy of Science 48: 325-354.

Smith, H.M. and E.H. Taylor. 1966. Herpetology of Mexico. Annotated Checklist and Keys to Amphibians and Reptiles. A reprint of Bulletins 187, 194, and 199 of the United States National Museum with a list of subsequent taxonomic innovations. Eric Lundberg, Ashton, Maryland, USA.

Uetz, P., P. Freed, and J. Hošek, J. 2019. The Reptile Database. <http://www. reptile-database.org>.

Wasko, D.K. and M. Sasa. 2009. Activity patterns of a Neotropical ambush predator: Spatial ecology of the Fer-de-lance (Bothrops asper, Serpentes: Viperidae) in Costa Rica. Biotropica 41: 241-249. 